\section{Use of endoclips to close sphincterotomy-related perforation}

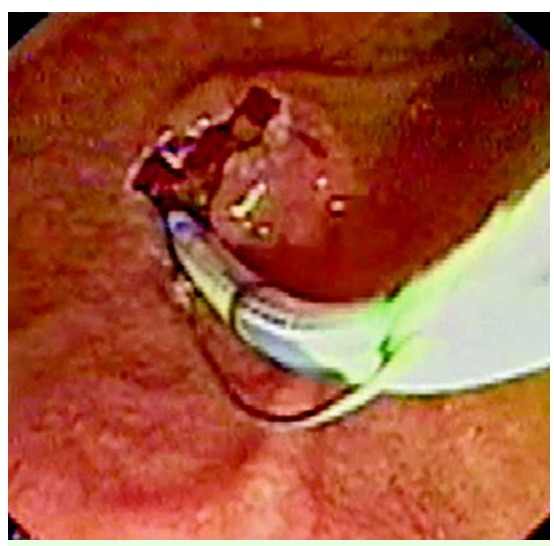

Fig. 1 A sphincterotomy-related perforation occurred at the 11-o'clock area of the ampulla.

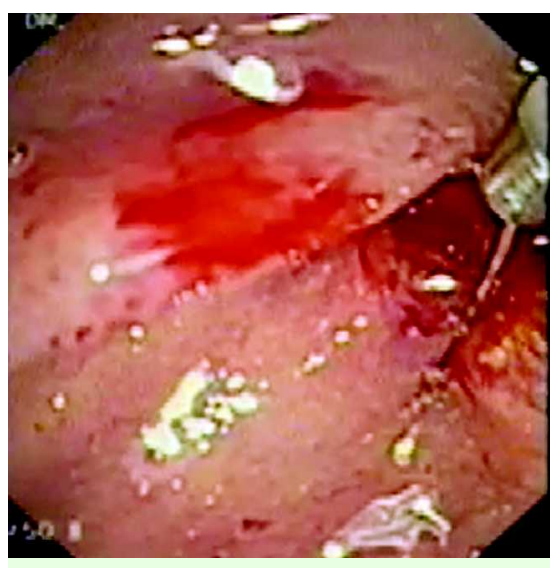

Fig. 2 The first endoclip is deployed through the side-viewing scope.

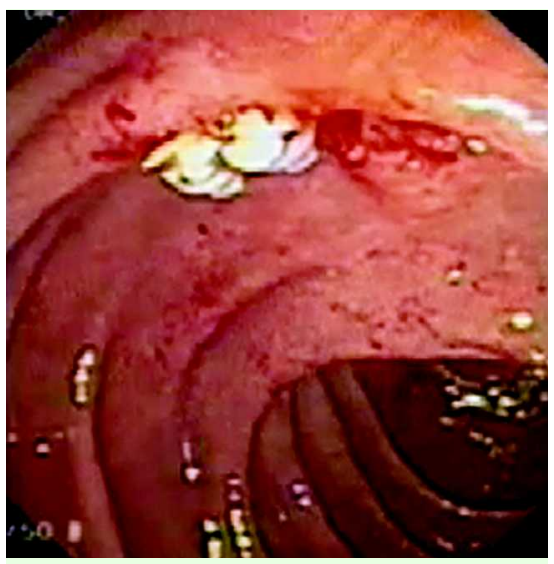

Fig. 3 Appearance when two endoclips had been placed.
A 26-year-old woman underwent biliary sphincterotomy after a diagnosis of sphincter of Oddi dysfunction. A 3-cm monofilament standard sphincterotome with blended current was used and a zipper cut occurred, causing a tear at the 11o'clock area of the ampulla ( Fig. 1 and - Video 1). Fluoroscopy showed a significant amount of free air in the retroperitoneal area. Initially, a gastroscope endoclipping device (HX-5LR-1; Olympus, Tokyo, Japan) and clips (HX-600-090L; Olympus) were deployed through the same side-viewing therapeutic duodenoscope (TJF 160; Olympus). There was marked difficulty in opening, rotating, and closing the clips; the endoscope elevator had to be locked at the open position during the deployment. Two clips were satisfactorily deployed before there was a malfunction of the clip handle ( Fig. 2 and 3, Videos 1 and 2). The more easily deployed third endoclip was placed using a disposable system (HX201LR-135; Olympus). Biliary and luminal decompression were achieved endoscopically. A broad spectrum antibiotic was given. The patient was able to resume her diet and all tubes were removed within 10 days. A computed tomography (CT) scan 3 months later showed no evidence of retroperitoneal air.

Most perforations following biliary sphincterotomy can be managed by nonoperative methods, including biliary and duodenal drainage [1]. If duodenal closure by surgery is planned, the tear is very difficult to access due to its retroperitoneal location. Hemoclipping has been well accepted for endoscopic control of many gastrointestinal perforations $[2,3]$. It has been reported that duodenal closure using this technique via the duodenoscope was more difficult than via the

\section{Video 1}

Perforation of the ampulla.

\section{Video 2}

Placement of first endoclips through the side-viewing scope (1).

Placement of first endoclips (2) end-viewing scope $[4,5]$. The limitations are the angle and stress created by the elevator of the scope and this in turn can lead to damage of the endoclipping device. We therefore recommend using a disposable endoclipping device in this situation since it has a slimmer delivery system and is more flexible in manipulation.

Endoscopy_UCTN_Code_TTT_1AR_2AC Endoscopy_UCTN_Code_TTT_1AR_2AJ

\section{R. Rerknimitr ${ }^{1}$, S. Aekpongpaisit ${ }^{2}$, \\ P. Kullavanijaya ${ }^{1}$}

Faculty of Medicine, Chulalongkorn University, Bangkok, Thailand

2 Department of Gastroenterology, Samitivej Hospital, Bangkok, Thailand

\section{References}

1 Fatima J, Baron TH, Topazian MD et al. Pancreaticobiliary and duodenal perforations after periampullary endoscopic procedures: diagnosis and management. Arch Surg 2007; 142: 448-454

2 Sung HY, Kim JI, Cheung DY et al. Successful endoscopic hemoclipping of an esophageal perforation. Dis Esophagus 2007; 20: 449 452

3 Fujishiro M, Yahagi N, Kakushima $N$ et al. Successful nonsurgical management of perforation complicating endoscopic submucosal dissection of gastrointestinal epithelial neoplasms. Endoscopy 2006; 38: $1001-1006$

4 Baron TH, Gostout CJ, Herman L. Hemoclip repair of a sphincterotomy-induced duodenal perforation. Gastrointest Endosc 2000; 52: $566-568$

5 Katsinelos P, Paroutoglou G, Papaziogas B et $a l$. Treatment of a duodenal perforation secondary to an endoscopic sphincterotomy with clips. World J Gastroenterol 2005; 11: $6232-6234$

\section{Bibliography}

DOI 10.1055/s-2007-995794

Endoscopy 2008; 40: E169

(c) Georg Thieme Verlag KG Stuttgart · New York . ISSN 0013-726X

Corresponding author

\section{R. Rerknimitr, MD}

Faculty of Medicine

Chulalongkorn University

Rama IV

Bangkok 10330

Thailand

Fax: +66-2-2527839

rungsun@pol.net 